\title{
Relationships Between Social Media News About Covid-19 and Level of Alertness on Family with Stunted Children in Tasikmalaya City
}

\section{Hilman Mulyana1, Tukimin Bin Sansuwito ${ }^{2}$, And Ate Nandang ${ }^{3}$}

${ }^{1}$ Lecturer in Nursing Undergraduate Study Program, Faculty of Nursing, Bhakti Kencana University, Tasikmalaya

${ }^{2}$ Lecturer in Faculty of Nursing, Lincoln University College, Malaysia

${ }^{3}$ Student of Nursing Undergraduate Study Program, Faculty of Nursing, Bhakti Kencana University, Tasikmalaya

ORCID:

Hilman Mulyana: https://orcid.org/0000-0002-1816-4607

\section{Abstract}

The high prevalence of Covid-19 can have quite serious physical and psychological

Corresponding Author:

Hilman Mulyana

h_main@ymail.com

Published: 15 March 2021

Publishing services provided by Knowledge E

(c) Hilman Mulyana et al. This article is distributed under the terms of the Creative Commons Attribution License, which permits unrestricted use and redistribution provided that the original author and source are credited.

Selection and Peer-review under the responsibility of the IVCN Conference Committee. impacts. The coverage on social media about the Covid-19 outbreak is sometimes wrongly interpreted by readers, such as families who have stunted children who are perceived to be at high risk for Covid-19. The aim of this study is to find out the relationship between social media news about Covid-19 and the level of vigilance displayed by families with at-risk children in this category. Correlational analysis was used with cross-sectional approach to asses a sample of 75 families residing in the Kawalu district, and a questionanaire was used as the research instrument. with a research instrument in the form of a questionnaire. Statistical tests were conducted which employed the Spearman rank. The results indicate that the relationship between social media news about Covid-19 and the level of vigilance displayed by families with children in this vulnerable category was ( $p$-value $=0.004$ ), the use of social media to access Covid-19 news in the medium category is 66 people (88.0\%) and the alert level is in the medium category. as many as 68 people (90.7\%). Many adverts aim ton inspire fear in order to heighten subsceptibility to marketing messages. This has a particular impact on families where children have special dietary requirements to alleviate their medical conditions, and if these nutritional needsd are not met there is a risk that their condition will intensify. It is particularly important, therefore, that public health center nurses focus on direct messaging to the affected families during the pandemic and in its aftermath.

Keywords: Covid-19, Level of Alertness, Social Media News, Stunting.

\section{Introduction}

The World Health Organization (WHO) on 19 July 2020 stated that there were around G OPEN ACCESS 
Covid-19 attacks 216 countries and one of them is a developing country like Indonesia, this virus is a disease that attacks the lungs which are characterized by symptoms of shortness of breath, one of them [9].

Based on data from the Indonesian Ministry of Health, the first case of contracting Covid-19 in Indonesia was because the citizen had direct contact with a Japanese citizen, which was the 24th confirmed case in Malaysia, after this incident other cases began to emerge and spread throughout Indonesia. On 19 July 2020, the number of Covid-19 patients in Indonesia was 88,214 confirmed positive, 36,998 patients under surveillance (PDP), and 46,977 Covid-19 patients, while 4,239 patients who died [8].

The percentage of Covid-19 incidents in West Java province until July 202020 was 5,548 people, Patients Under Supervision (PDP) as many as 875 people, People Under Supervision (ODP) as many as 1,540 people, and 2,272 people who were successfully cured, but there were 190 people who died due to the virus [6]. The West Java Provincial Government has formed a Covid-19 Response Task Force (SATGAS) Team that has been deployed to the city and district levels.

Tasikmalaya City is one of the cities in the province of West Java and is infected with Covid-19 with 36 positive people, 1,366 people under surveillance (ODP), 51 patients under surveillance (PDP), and 8 deaths. the data is as of 19 July 2020 [5]. Kelurahan Gunung Gede RW 03, Kawalu sub-district is one of the sub-districts located in the City of Tasikmalaya, West Java province and is not flat from exposure to Covid-19, the number of sufferers is 5 people and it is possible that it will continue to increase every day, every week and the following months because this virus has the potential to develop due to the geographical conditions of the city of Tasikmalaya as a support for other large cities such as Bandung and Jakarta and the mobility of its occupation back and forth from these cities [5].

Covid-19 has the potential to attack almost all ages and groups and it has been recorded that in several countries this case attacks at vulnerable ages or at high risk of contracting the virus such as the elderly and toddlers. This viral infection begins with droplets produced during coughing and sneezing by symptomatic patients, but the transmission of this virus can also be from patients who do not have signs and symptoms of the virus [21].

A person can become infected with Covid-19 by simply inhaling direct droplets from a positive patient or touching a surface contaminated with the virus and then touching one's own face, this can also be a process of transmission. The dangers of Covid-19 and this behavior are of course a special concern, especially for people who are at high 
risks, such as toddlers or toddlers who have a relatively low immune system to fight Covid-19

Children with normal growth and development still have great potential to be exposed to Covid-19, this is evidenced by cases in the category of children in several countries. Children with stunted conditions are strongly adhered to by good nutritional intake so that their conditions do not continue to get worse and can maintain their immune system, children are stunted or conditions of failure to thrive in children due to malnutrition in West Java, one of the provinces that has increased stunting from year to year, count since 2015 it was $25.6 \%$ until 2019 to 38\%, this means that within 5 years there has been an increase of around $12.4 \%$. Tasikmalaya City is one of the cities in the province of West Java with the prevalence of stunting in 2019 increasing from 10.8 percent to 10.95 percent of all children born and is predicted to increase in 2020 due to the impact of the Covid-19 pandemic [2].

The condition of the Covid-19 pandemic which was evenly distributed throughout the world, especially in Indonesia, resulted in the public consuming a lot of news related to Covid-19, both positive and negative news. This news makes most people panic excessively, which makes people afraid to interact socially [21]. Since the outbreak of the Covid-19 outbreak, visits to supermarkets in various cities in the world have presented almost the same view including in Indonesia, empty food shelves because they are bought, it is difficult to find masks, hand sanitizers, or even this anti-germ soap which is called the panic buying effect.

One of the types of media that are often used to report about Covid-19 is social media which is very effective in disseminating information because social media is directly and closely related to the millennial era. So that it makes information quickly widely known by the public, both young and elderly [18]. According to Moohead [14], social media can function as sharing for information, increasing accessibility and access to health information, social, and emotional support and tools that can be used to influence policies in terms of one's behavior.

Social media intentionally sends true or false health information on the power of the account owner [4]. Kaya, M. [10], said that social media has become one of the media for education. In the current millennial era, social media has become an inevitable source of health information for most Indonesians, and especially in community nursing care, it has become an integral part of the education media for the community. This situation indicates that in addition to functioning as a medium of entertainment, social media can be used as an alternative source of answers to questions in everyday life, including information about Covid-19. 
News or information coverage about health and the development of the medical world can save lives but can also be worrying and misleading for someone [11]. A lot of news on social media about the Covid-19 epidemic is impressive to frighten someone so that it creates persuasive messages that can cause fear to someone by describing threats that are serious and may happen to someone who reads the news. The news created the perception of the community, especially family who have children with stunted conditions, to increase awareness of what they read and know.

The level of vigilance, especially family who have children with stunting conditions in the city of Tasikmalaya, is quite low, the results of observations and news are currently being reported that children and even adolescents in the city of Tasikmalaya have fun playing football on the highway at the time of PSBB (Large-Scale Social Restrictions) are being implemented. Based on the results of interviews with family who have children with a stunting condition related to the level of awareness of Covid-19, according to them, children with stunted conditions are the same as normal children. The health cadres also said the same thing that the family lacked a level of vigilance, underestimating government recommendations as if there was no pandemic.

The amount of news through social media about Covid-19, if not understood properly, will be very dangerous for readers, especially family who have children with stunted conditions. This study analyzed the relationship between this news and the level of alertness in stunting children.

\section{Research Methods}

The research method used is descriptive correlational analytic to explain/describe the characteristics of each variable and find relationships between variables and other variables through the use of correlation statistics [22]. The sample in this study were 75 family who had stunted children in the city of Tasikmalaya by paying attention to the inclusion and exclusion criteria, the questionnaire used was in the form of a checklist and consisted of positive and negative question items containing information about social media, copid-19 precautions, and stunting that had been expertly tested by Ns. $\mathrm{Hj}$. Euis Teti Hayati, S.Kep., M.Kep health at the puskesmas and Encu Darsiwa, S.Kep., S.Sos., MH.Kes health from the Tasikmalaya city health department.

The data obtained from the results of this study were processed manually by assessing the questionnaire sheets that were distributed and then analyzed using a statistical processing program. The next stage is processed using a computerized system, these stages include editing, coding, tabulating, and data entry. The final stage of the data is 
analyzed univariate in the form of frequency distribution and bivariate analysis with the Rank Spearmen test with a significant level of $5 \%(\alpha$ 0.05). This research uses human objects, so researchers need to pay attention to things such as informed consent, anomity and confidentiality from respondents.

\section{Result}

\subsection{Univariate Analysis}

TABLE 1: Overview of Accessing News on Social Media.

Category
Height
Medium
Low
Total

$\mathbf{N}$
-
66
9
75

\begin{tabular}{|c|}
\hline$\%$ \\
\hline- \\
\hline $88,0 \%$ \\
\hline $12,0 \%$ \\
\hline $100 \%$ \\
\hline
\end{tabular}

From table 1 above shows that family who have children with stunting conditions access news in the medium category the most as many as 66 people (88.0\%)

TABLE 2: Description of Alert Level

Category
Height
Medium
Low
Total

\begin{tabular}{|c|}
\hline $\mathbf{N}$ \\
\hline 2 \\
68 \\
\hline 5 \\
75 \\
\hline
\end{tabular}

\begin{tabular}{|c|}
\hline$\%$ \\
\hline $2,7 \%$ \\
\hline $90,7 \%$ \\
\hline $6,7 \%$ \\
\hline $100 \%$ \\
\hline
\end{tabular}

From table 2 above, it shows that family who have children with stunting are at the most alert level with the moderate category as many as 68 people (90.7\%).

\subsection{Bivariate Analysis}

The relationship of social media news about Covid-19 to the level of vigilance of family who have children with stunting conditions.

Based on table 3, it shows that most family who have children with stunted conditions in accessing social media are included in the moderate alert level category, amounting to 63 people (95.5\%). While the number sig. (2-tailed) is 0.004 which is still smaller than the critical limit $\alpha=0.05$, this indicates that there is a significant relationship between the two variables $(0.004<0.05)$. 
TABLE 3

\begin{tabular}{|c|c|c|c|c|c|c|c|c|c|}
\hline \multirow[t]{3}{*}{ Social Media News } & \multicolumn{6}{|c|}{ Family Vigilance } & \multirow[t]{3}{*}{ Total } & \multirow[t]{3}{*}{$\%$} & \multirow{3}{*}{$\begin{array}{c}p- \\
\text { value }\end{array}$} \\
\hline & \multicolumn{2}{|c|}{ Height } & \multicolumn{2}{|c|}{ Medium } & \multicolumn{2}{|c|}{ Low } & & & \\
\hline & $\mathbf{n}$ & $\%$ & $\mathbf{n}$ & $\%$ & $\mathbf{n}$ & $\%$ & & & \\
\hline Medium & 2 & $3.0 \%$ & 63 & $95.5 \%$ & 1 & $1.5 \%$ & 66 & 100 & \\
\hline Low & 0 & $0.0 \%$ & 5 & $55,6 \%$ & 4 & $44.4 \%$ & 9 & 100 & 0.004 \\
\hline Total & 2 & $2,7 \%$ & 68 & $90.7 \%$ & 5 & $6,7 \%$ & 75 & 100 & \\
\hline
\end{tabular}

\section{Discussion}

\subsection{Social Media News}

The results showed that respondents who accessed the highest news with the medium category were 66 people (88.0\%), while for the low category, the use of social media to access news was 9 people (12.0\%). Looking at the data, it shows that family who have children with stunting conditions in accessing news, especially about Covid-19, are more in the medium category.

Social media is a means of conversation that occurs on the internet and is supported by tools in the form of applications or software and social networking is a social structure consisting of individual or organizational elements, this social network shows how they relate because of the similarity of sociality, starting with those known every day to family $[11,16,24]$.

Respondents who use social media based on gender are mostly dominated by women compared to men in this study are women who act as mothers and men who act as fathers, this is in accordance with the results of research by Syamsoedin et al [23], which states that that women have more desire to interact with other people through social media. Based on these facts and theories, the researchers assume that mothers of children who are stunted have a high enough curiosity about the latest news on social media, especially about the Covid-19 pandemic. The researcher also assumed that the respondents mostly read the message but sometimes it was incomplete, it was also found that the respondents did not read the message but immediately disseminate it through the same or different social media.

\subsection{Level of Alert}

The results showed that the highest level of alertness for Covid-19 was 68 people (90.7\%), while for the lowest category there were only 2 people $(2.7 \%)$ in the high 
category. These results show that family who have children with stunted conditions have a moderate level of alertness in the category of preventing the transmission of Covid-19, the researchers assume that the family applies or understands the information obtained through social media, but the truth of the information really must be considered by the family.

Vigilance is the mental attitude of a nation that is always ready to face all kinds of threats, challenges, obstacles, and disturbances that will arise one day, including the individual [17]. Many messages on social media have the impression of scaring someone so that they create persuasive messages that cause fear in the person, depicting serious threats and might happen to someone who reads the news. The news causes a person's perception to immediately raise awareness of what he reads and knows.

With a lot of news about the Covid-19 outbreak, it gradually affects family who have children with stunted conditions that are very worried and create excessive fear so that to prevent and increase awareness, family members often wash their hands using water and soap for at least 20 seconds each activity, especially before leaving the house, before eating and after coughing or sneezing always washing hands, avoiding close contact with sick people, covering your mouth when coughing and sneezing using a tissue, avoiding touching your face before washing your hands and many family who come and ask questions to the post Covid-19 closest [7].

At the beginning of the pandemic, almost all family members felt paranoid obout all their activities because of the news they received, but in the end, with a campaign from the Covid-19 management health officer in the city of Tasikmalaya, the family could understand the current conditions so that the family could raise their awareness properly. The new fact that emerges is that the habit of increasing awareness is slowly decreasing over time, the researchers assume that people have started to feel bored with this new habit of increasing awareness of this Covid-19 and the economic situation has decreased as a bad impact of the pandemic.

Facing the current situation, the participation of the community or family is very important in increasing awareness of the spread of Covid-19 to stunting children. Empowerment of familiy as the smallest unit of society has long been a solution to overcoming health problems. Laili \& Andriani [12], state that society has an important role in preventing stunting, understanding cadres, and family in preventing stunting can determine the success of stunting prevention programs.

The Indonesian government has taken a stand by Government Regulation Number 21 of 2020 concerning Large-Scale Social Restrictions in the Context of Accelerating the Handling of Covid-19. This step is in line with Zhang, Zhao, \& Hu [25], that when a 
pandemic must break the chain of transmission, which aims to protect the population. Stopping the chain of spread can be done by washing hands frequently, staying at home and reducing contact with other people, and using protection when you want to leave the house [13]. Maintaining social distancing is also one way to reduce the spread of Covid-19 [20]. These steps should make family who have stunted children with nutritional conditions and immune systems that are low compared to children with normal conditions to increase their alertness level.

\subsection{Relationship of Social Media News About Covid-19 Against the Vigilance Level of Family with Stunting Children}

Based on the results of this study, it shows that the highest respondent with the category of using social media news with a moderate level of alertness is 63 people (95.5\%) and the lowest score is the category of using social media news with a moderate level of alertness as many as 1 person (1.5\%). Researchers can conclude that based on the results of this study, the majority of family who have children with stunted conditions have a moderate level of alertness. Strengthened by the results of statistical tests, where the $p$-value is $0.004(\alpha<0.05)$ with a correlation coefficient of 0.498 , this figure shows a correlation between variables so that it can be said that there is a significant relationship between social media news about Covid-19 on the level of family vigilance. have children with stunting conditions in the city of Tasikmalaya in 2020.

Based on the facts, the theory and the results of this research, the researcher assumes that many advertisements are impressive to frighten someone so that it makes messages become persuasive which actually creates fear in someone by describing serious threats. The news creates a person's perception to increase awareness of what he reads and understands.

This study uses a sample of family, especially mothers who have children who are stunted at the time of the study, where at this time, as a result of the pandemic, there are often economic conflicts within the family so that it affects the fulfillment of children's nutritional needs, if the child's nutrition is not fulfilled, the current situation it will make the stunting child's condition worse. The news about the Covid-19 epidemic made family very worried not only for children who were stunted but for all family members, causing excessive fear in preventing and increasing awareness [7].

Social news about precautions that can be done at home during the Covid-19 pandemic, one of which is Clean and Healthy Living Behavior (PHBS). In line with the 
research results of Anhusadar, L., \& Islamiyah, I. [1], as many as $100 \%$ of parent respondents saw the importance of implementing PHBS during the Covid-19 pandemic and the implementation of PHBS in early childhood in the family environment in this pandemic was very good. The results of this study can certainly be carried out on family who have children with stunted conditions, and the support of all family members can be a power in filtering information and increasing awareness [15].

\section{Conclusion}

It is known that there is a significant relationship between reporting on social media about the Covid-19 pandemic in Indonesia, especially the city of Tasikmalaya, and the level of vigilance in dealing with it in family who have children with stunted conditions.

A new fact that has emerged at this time is the habit of increasing Covid-19 awareness in a new life (new normal), over time it slowly begins to decline, so there needs to be education from health workers in increasing public awareness in increasing Covid-19 awareness more extra or by binding regulations.

\section{References}

[1] Anhusadar, L. and Islamiyah, I. (2020). Penerapan Perilaku Hidup Bersih dan Sehat Anak Usia Dini di Tengah Pandemi Covid 19. Jurnal Obsesi: Jurnal Pendidikan Anak Usia Dini, vol. 5, issue 1, pp. 463-475.

[2] Dinkes Kota Tasikmalaya. (2020). Profil Kesehatan Dinas Kesehatan Kota Tasikmalaya. Indonesia: Jawab Barat.

[3] Efrizal, W. (2020). Berdampakkah Pandemi Covid-19 terhadap Stunting di Bangka Belitung? Jurnal Kebijakan Kesehatan Indonesia: JKKI, vol. 9, issue 3, pp. 154-157.

[4] Hanson, C., et al. (2011). Use and Acceptance of Social Media among Health Educators. American Journal of Health Education, vol. 42, issue 4, pp. 197-204.

[5] Diskominfo. April. (2020). Retrieved April 20, from https://diskominfo.tasikmalaya.go. id.

[6] Pikobar. April. (2020). Retrieved April 20, from https://pikobar.jabarprov.go.id/.

[7] Cigna.co.id. Maret. (2020). Retrieved April 23, 2020 from https://www.cigna.co.id/ health-wellnes/yang-anda-perlu-ketahui-tentang-coronavirus.

[8] Kemkes.go.id. April. (2020). Retrieved April 23, 2020 from https://www.kemkes. go.id/article/view/20012900002/kesiapsiagaan-menghadapi-infeksi-Novelcoronavirus.html 
[9] WHO. Desember. (2019). Retrieved April 20, 2020 from https://www.who.int/ emergencies/diseasis/novel-coronavirus-2019.

[10] Kaya, M., Birinci, Ș., Kawash, J., \& Alhajj, R. (Eds.). (2019). Putting Social Media and Networking Data in Practice for Education, Planning, Prediction and Recommendation. Springer Nature. Switzerland, AG.

[11] Khairuni, N. (2016). Dampak Positif dan Negatif Sosial Media Terhadap Pendidikan Akhlak Anak (Studi Kasus di SMP Negeri 2 Kelas VIII Banda Aceh). Jurnal Edukasi, vol. 2, issue 1, hal 35-45. ISSN:2460-4917 E-ISSN:2460-5794

[12] Laili, U. and Andriani, R. A. D. (2019). Pemberdayaan Masyarakat Dalam Pencegahan Stunting. Jurnal Pengabdian Masyarakat IPTEKS, vol. 5, issue 1, pp. 8-12.

[13] Li, B. Z., Cao, N. W., Zhou, H. Y., Chu, X. J., \& Ye, D. Q. (2020). Strong policies control the spread of COVID-19 in China. Journal of medical virology, 92(10), 1980-1987.

[14] Moorhead, S., et al. (2013). Nursing Outcomes Classification (NOC) ( $5^{\text {th }}$ ed.). Jakarta: Elsevier.

[15] Mulyana, H. (2017). Hubungan Dukungan Keluarga Dengan Keteraturan Anc Ibu Hamil Aterm Yang Mengalami Hipertensi. Jurnal Keperawatan BSI, vol. 5, issue 2, 92-102.

[16] Rulli, N. (2012). Internet dan Ruang Publik Virtual, Sebuah Refleksi atas Teori Ruang Publi Habermas. Fakultas IImu Dakwah dan IImu Komunikasi UIN Syarif Hidayatullah, Jurnal Komunikator, vol. 4, issue 1, h. 36-16.

[17] Pratama, A. and Husin, A. (2018). Partisipasi Tokoh Masyarakat dalam Kewaspadaan Penyalahgunaan Narkotika. Journal of Nonformal Education and Community Empowerment, vol. 2, issue, h. 49-59.

[18] Putri, N. S., Rochim, A. F. and Windasari, I. P. (2013). Perancangan Sistem Informasi Rekam Medis Rawat Inap Rumah Sakit Berbasis Web. Jurnal Teknologi dan Sistem Komputer, vol. 1, issue 1, pp. 1-13.

[19] Richert, R. A., Robb, M. B. and Smith, E. I. (2011). Media as Social Partners: The Social Nature of Young Children's Learning from Screen Media. Child Development, vol. 82, issue 1, pp. 82-95.

[20] Sen-Crowe, B., McKenney, M. and Elkbuli, A. (2020). Social Distancing during the COVID-19 Pandemic: Staying Home Save Lives. American Journal of Emergency Medicine, vol. 38, issue 7, pp. 1519-1520.

[21] Singhal, T. (2020). A Review of Coronavirus Disease-2019 (COVID-19). The Indian Journal of Pediatrics, vol. 87, issue 4, pp. 281-286.

[22] Suharsaputra, U. (2018). Supervisi Pendidikan: Pendekatan Sistem Berbasis Kinerja. Bandung: PT Refika Aditama. 
[23] Syamsoedin, W. K. P., Bidjuni, H. and Wowiling, F. (2015). Hubungan Durasi Penggunaan Media Sosial Dengan Kejadian Insomnia Pada Remaja di SMA Negeri 9 Manado. Jurnal Keperawatan, vol. 3, issue 1, h. 01-10.

[24] Tolhah, H. (2015). Penggunaan Multimedia Berbasis Komputer. Madaniyah, vol. 5, issue 1, pp. 87-108.

[25] Zhang, Y., Zhao, Q. and Hu, B. (2020). Community-based prevention and control of COVID-19: Experience from China. American Journal of Infection Control, vol. 48, issue 6, pp. 716-717, https://doi.org/10.1016/j.ajic.2020.03.012. 